\title{
EFFECT OF INCREASED SERUM SULPHYDRYL CONTENT ON TITRE OF RHEUMATOID FACTOR*
}

\author{
BY \\ ISRAELI A. JAFFE AND PARVIN MERRYMAN \\ Department of Medicine, New York Medical College, New York, N.Y.
}

The prolonged administration of the sulphydryl compound penicillamine to rheumatoid arthritis patients results in a fall in the titre of rheumatoid factor (Jaffe, 1963). The mechanism by which the drug produces this effect is unknown, though it does not appear to be by intravascular depolymerization of macroglobulins (Jaffe, 1964) or by immunosuppression by pyridoxine antagonism (Jaffe, 1965). It has been reported that the serum sulphydryl content is abnormally low in patients with rheumatoid arthritis, and that the deficiency in protein sulphydryl groups may be responsible for the formation of abnormal immunoglobulins including rheumatoid factor (Lorber, Pearson, Meredith, and Gantz-Mandell, 1964). The restoration of the depressed serum sulphydryl content by penicillamine was suggested as a possible mechanism to explain the fall in rheumatoid factor titre and clinical improvement observed following a course of treatment with this drug (Lorber, 1966). The purpose of this study was to test that hypothesis by correlating the changes in rheumatoid factor and the serum sulphydryl content induced by THREE sulphydryl compounds systemically administered to two patients with rheumatoid arthritis.

\section{Methods}

The two patients studied had active long-standing rheumatoid arthritis and were in anatomical Stage IV by the criteria of The American Rheumatism Association (Steinbrocker, Traeger, and Batterman, 1949). They were hospitalized throughout the entire period of the investigation. Blood specimens were obtained weekly in the fasting state for determination of serum sulphydryl content and rheumatoid factor. The serum sulphydryl determinations were made within 4 hours of venepuncture, by a modified amperometric titration using a \footnotetext{
*This study was supported by the U.S. Army Medical Research and
Development Command (DA-49-193MD-2445).
}

Sargent-XV polarograph (Lorber and others, 1964). $\frac{\stackrel{2}{2}}{2}$ Serum samples from each treatment period were sub-ĩ jected to ultrafiltration for determination of the sulphy- dryl content of the filtrates. Rheumatoid factor was:measured immunochemically by the quantitative preci- $\rightarrow$ pitin technique (Franklin and Kunkel, 1957; Edelman,으 Kunkel, and Franklin, 1958), in which increasing amountsof heat-aggregated human gamma globulin were added c to the test serum and the protein content of the resulting precipitates was determined. The serum of Patient 2 was diluted $1: 2$ with saline in order to obtain a suitable curve as evidenced by a fall in the protein content of the $\vec{\bullet}$ precipitate in the region of antigen excess. The drussso employed in the study were D-penicillamine, $\mathrm{N}$-acees $\mathrm{l}^{-}$ D-penicillamine, and mercaptoethylamine (cysteamige) (Fig. 1). All drugs were given in four divided doses, afters meals and at bedtime. The daily dosage of D-penicilla- $\bar{O}$ mine and $\mathrm{N}$-acetyl D-penicillamine was $2.0 \mathrm{~g}$., and that of mercaptoethylamine $2.4 \mathrm{~g}$. Each period of study lasted approximately 16 weeks. The patients were care- $\Rightarrow$ fully observed clinically and by appropriate laboratoryo tests for signs of drug toxicity.

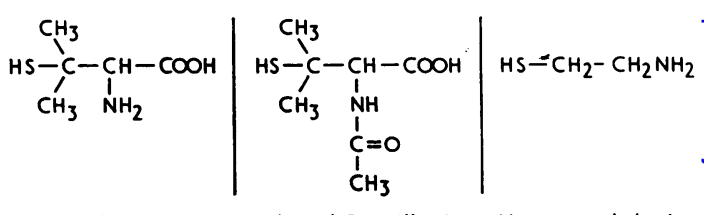

Penicillamine N-Acetyl Penicillomine Mercoptoethylamine

Fig. 1.-Structural formulae of the three sulphydryl compounds? employed in the study.

\section{Results}

The serum sulphydryl content in normal subjectsin was $400-600 \mu \mathrm{M} /$ litre, in agreement with the values that had previously been reported (Lorber and $\omega$ others, 1964). The reproducibility of sulphydry? determinations on the same specimen was withife 5 per cent. Ultrafiltration of sera obtained during each treatment period showed virtually no free sulphydryl groups in the filtrates (less than $4 \mu \mathrm{M} / 1$.). 
As shown in the Table, both patients had a low serum sulphydryl content before the administration of one of the thiol compounds, and the values rose during each course. The MAGNITUDE of the increase and the RATE at which it occurred was similar for each drug, and once the maximum concentration was achieved it remained relatively stable (Table).

The relation between the serum sulphydryl content and the rheumatoid factor titre at the beginning and end of each period is shown in Figs 2 and 3. Although the increase in serum sulphydryl content was remarkably constant for each course of thiol compound administered, the titre of rheumatoid factor fell only after D-penicillamine treatment.

No significant clinical changes in these patients with end-stage disease were observed with any course, regardless of the presence or absence of reductions in titre.

TABLE

SERUM SULPHYDRYL CONCENTRATIONS $(\mu \mathrm{M} / 1$.$) DURING COURSES OF THIOL ADMINISTRATION$

\begin{tabular}{|c|c|c|c|c|c|c|c|c|}
\hline \multirow{2}{*}{$\frac{\text { Patient No. }}{\text { Course No. }}$} & \multirow{2}{*}{$\cdots$} & \multirow{2}{*}{$\begin{array}{ll}\cdots & \cdots \\
& \cdots\end{array}$} & \multicolumn{4}{|c|}{1} & \multicolumn{2}{|c|}{2} \\
\hline & & & 1 & 2 & 3 & 4 & 1 & 2 \\
\hline & & Control & 296 & 292 & 290 & 300 & 300 & 324 \\
\hline $\begin{array}{l}\text { Weeks } \\
\text { of } \\
\text { Treatment }\end{array}$ & & $\begin{array}{r}2 \\
4 \\
6 \\
8 \\
10 \\
12 \\
14 \\
16\end{array}$ & $\begin{array}{l}300 \\
300 \\
336 \\
360 \\
360 \\
352 \\
354 \\
360\end{array}$ & $\begin{array}{l}280 \\
312 \\
320 \\
340 \\
350 \\
370 \\
360 \\
368\end{array}$ & $\begin{array}{l}310 \\
310 \\
340 \\
348 \\
360 \\
370 \\
360 \\
360\end{array}$ & $\begin{array}{l}300 \\
320 \\
352 \\
360 \\
364 \\
360 \\
368 \\
370\end{array}$ & $\begin{array}{l}340 \\
390 \\
380 \\
372 \\
408 \\
400 \\
404 \\
404\end{array}$ & $\begin{array}{l}344 \\
360 \\
396 \\
400 \\
388 \\
384 \\
392 \\
408\end{array}$ \\
\hline
\end{tabular}

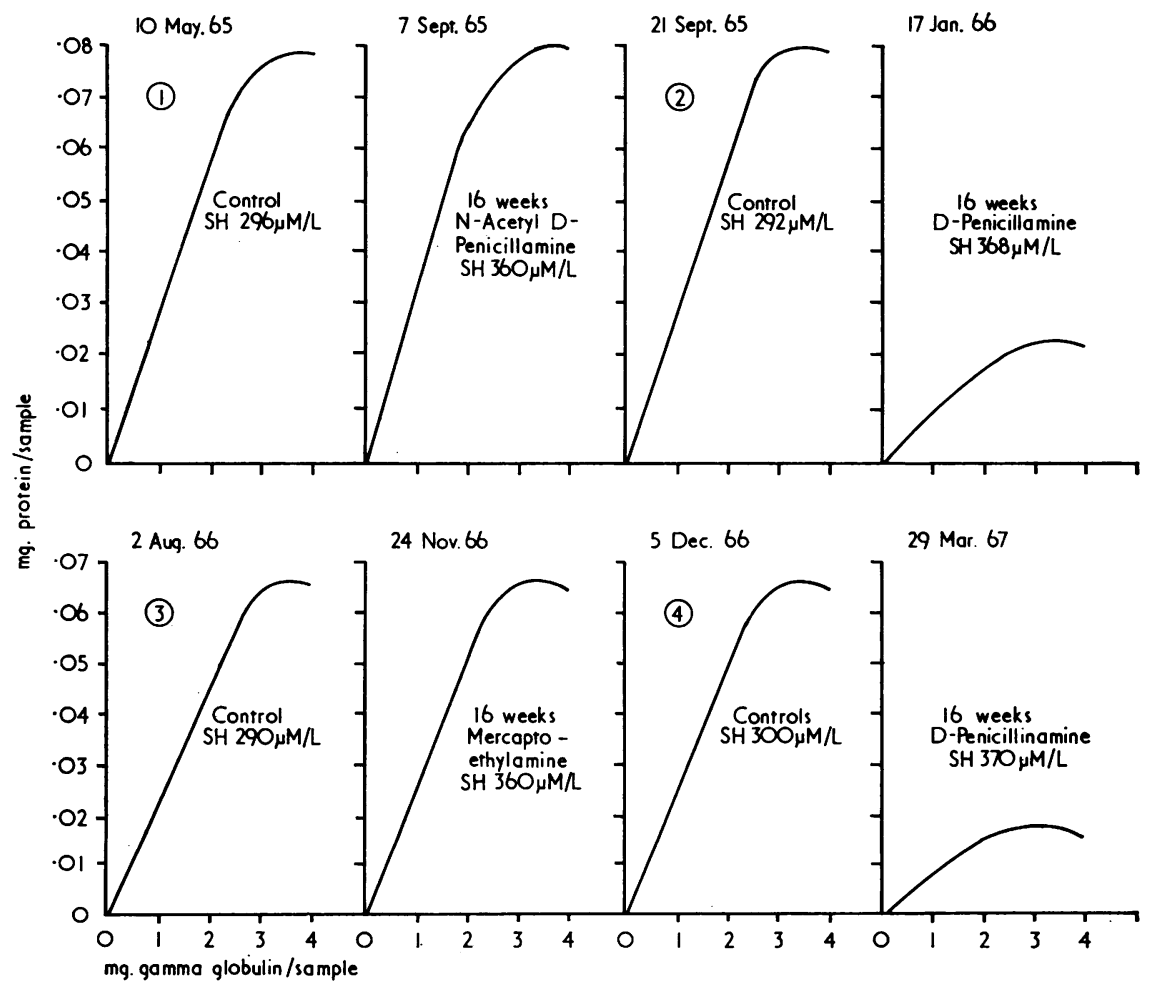

Fig. 2.-Effect of the three sulphydryl compounds on the titre of rheumatoid factor in the same patient. The height of the curve indicates the amount of precipitable rheumatoid factor after the addition of increasing amounts of aggregated gamma globulin to each serum specimen, Only courses 2 and 4 , when D-penicillamine was given, resulted in a fall in titre. Note that the maximum sulphydryl concentrations produced by all drugs was virtually identical. 


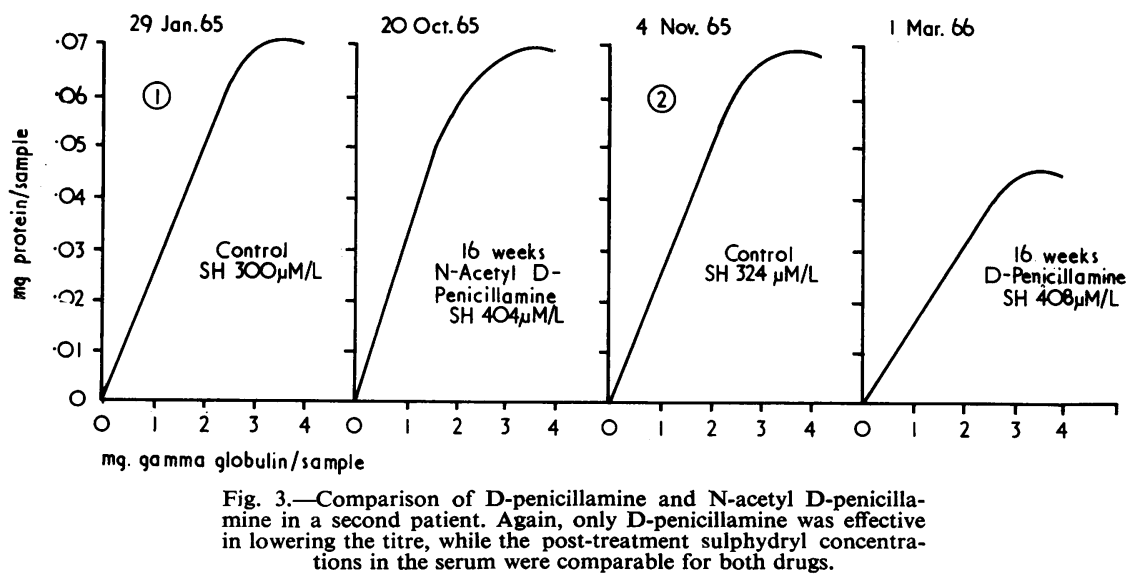

\section{Discussion}

The results of this study confirm the observations that the serum sulphydryl content is low in patients with rheumatoid arthritis, that it can be raised by the administration of penicillamine, and that this is associated with a fall in rheumatoid factor titre. Before this elevation of serum sulphydryl content by penicillamine could be accepted as a possible mechanism of action of the drug, however, further studies with other thiol compounds appeared warranted in order to determine if there was any SPECIFITY to the penicillamine response. The other drugs were evaluated therefore with particular regard to their ability to increase the serum sulphydryl levels, and the effect, if any, of this increase upon the titre.

The data presented in the Table show that both $\mathrm{N}$-acetyl D-penicillamine and mercaptoethylamine produced a rise in serum sulphydryl content comparable to that achieved with penicillamine within the same length of time. The virtual absence of sulphydryl groups in the ultrafiltrates of serum obtained during treatment with all the drugs indicates that, in each instance, the sulphydryl was protein-bound. The failure of both $\mathrm{N}$-acetyl $\mathrm{D}$ penicillamine and mercaptoethylamine to produce a fall in titre is evidence that the elevation of the serum protein sulphydryl content is not per se responsible for the reduction in titre produced by penicillamine. This is in keeping with the fact that a depressed serum sulphydryl concentration is not a finding unique to the rheumatoid patient or to patients with other forms of macroglobulinaemia, but is found in many systemic diseases associated with serum protein abnormalities (Schoenbach, Weissman, and Armistead, 1951).

The particular molecular configuration of penicil- lamine must be required for certain specific sulphy $\Rightarrow$ dryl interactions in vivo, either directly on proteins or on protein synthesis. Alternatively, the drug might affect serum proteins primarily because of its metal-binding properties, the rise in serun? sulphydryl content merely reflecting the absorption of this or any other systemically administered thiof compound. Acetyl penicillamine has a differenf5 spectrum of chelation from that of penicillamme (Aposhian, 1960; Scheinberg, 1964), and mercapp toethylamine has not been demonstrated to bes. chelating agent in vivo. Since copper and othe divalent cations are essential as co-factors in manbै enzymatic reactions required for protein (antibody $\$$ synthesis, depletion of a trace metal or its binding at the cellular level might be expected to be inhibitory.

It is possible that the effect of penicillamine. administration on rheumatoid factor and its reported efficacy in other forms of macroglobulinaemi (Ritzmann, Coleman, and Levin, 1960; Edwards an Gengozian, 1965; Costanzi, Coltman, Clark, Tentnenbaum, and Criscuolo, 1965) share a commos mechanism. Although penicillamine therapy waš tried in such cases in an attempt to produce the intravascular dissociation of macroglobulins that can be accomplished in vitro by increasing the numo. ber of available sulphydryl groups (Ritzmann and others, 1960), the persistence of reduced macroglobulin levels for long periods after the drug was withdrawn has led several authors to question that this is the in vivo mechanism (Edwards an Gengozian, 1965; Costanzi and others, 1965). similar pattern of response has been an almost constant finding in the arthritis patients, in whom there has been a sustained reduction in rheumatoidp factor titre for many months after the termination 
of the penicillamine therapy (Jaffe, 1963, 1965). This is illustrated by Patient 1 (Fig. 2), whose titre failed to return to its previous control level $(8 / 2 / 66$ and $9 / 12 / 65$ ) many months after the first course of penicillamine was completed and the serum sulphydryl content had again fallen.

It is concluded that the mechanism of the in vivo effect of penicillamine on the rheumatoid factor, and perhaps on other macroglobulins as well, remains to be elucidated. Since penicillamine is a drug with many well-defined and diverse pharmacological properties, extrapolation from in vitro systems may be misleading. The failure of two other thiol compounds to induce a fall in rheumatoid factor titre while they significantly raised the serum protein sulphydryl content, and the lack of specifity of this biochemical abnormality for rheumatoid arthritis and other forms of macroglobulinaemia, suggests that this is not the mechanism of action of the drug.

\section{Summary}

The serum sulphydryl content was measured weekly in two patients with rheumatoid arthritis who were treated with three sulphydryl compounds: D-penicillamine, $\mathrm{N}$-acetyl D-penicillamine, and mercaptoethylamine. All these drugs produced a comparable increase in serum protein sulphydryl content within the same length of time. Rheumatoid factor titre fell, however, only during D-penicillamine administration. It is concluded that increasing the serum sulphydryl content is NOT the mechanism by which penicillamine produces a fall in rheumatoid factor titre. The particular sulphydryl reactivity of the penicillamine molecule or its specific chelating properties may be responsible for the effect of penicillamine on the titre in vivo.

The D-penicillamine and N-acetyl D-penicillamine was provided by Dr. Elmer Alpert, Merck Sharp and Dohme Research Laboratories, West Point, Pa.

\section{REFERENCES}

Aposhian, H. V. (1960). In "Metal-Binding in Medicine", ed. M. J. Seven and L. A. Johnson, p. 290. Lippincott, Philadelphia.

Costanzi, J. J., Coltman, C. A., Jr., Clark, D. A., Tennenbaum, J. I., and Criscuolo, D. (1965). Amer.J. Med., 39, 163 (Cryoglobulinemia associated with a macroglobulin).

Edelman, G. M., Kunkel, H. G., and Franklin, E. C. (1958). J. exp. Med., 108, 105 (Interaction of the rheumatoid factor with antigen antibody complexes and aggregated gamma globulin).

Edwards, C. L., and Gengozian, N. (1965). Ann. intern. Med., 62, 576 (Auto-immune hemolytic anemia treated with d-penicillamine).

Franklin, E. C., and Kunkel, H. G. (1957). J. Immunol., 78, 11 (Immunological differences between the $19 \mathrm{~S}$ and $7 \mathrm{~S}$ components of normal human gamma-globulin).

Jaffe, I. A. (1963). Ann. rheum. Dis., 22, 71 (Comparison of the effect of plasmapheresis and penicillamine on the level of circulating rheumatoid factor).

(1964). Ann. intern. Med., 61, 556 (Rheumatoid arthritis with arteritis. Report of a case treated with penicillamine).

- (1965). Arthr. and Rheum., 8, 1064 (The effect of penicillamine on the laboratory parameters in rheumatoid arthritis).

Lorber, A. (1966). Nature (Lond.), 210, 1235 (Penicillamine therapy for rheumatoid lung disease: effects on protein sulphydryl groups).

- - Pearson, C. M., Meredith, W. L., and Gantz-Mandell, L. E. (1964). Ann. intern. Med., 61, 423 (Serum sulfhydryl determinations and significance in connective tissue diseases).

Ritzmann, S. E., Coleman, S. L., and Levin, W. C. (1960). J. clin. Invest., 39, 1320 (The effect of some mercaptanes upon a macrocryogelglobulin; modifications induced by cysteamine, penicillamine and penicillin).

Scheinberg, I. H. (1964). J. chron. Dis., 17, 293 (D-pencillamine, with particular relation to Wilson's disease).

Schoenbach, E. B., Weissman, N., and Armistead, E. B. (1951). J. clin. Invest., 30, 762 (The determination of sulfhydryl groups in serum. II. Protein alterations associated with disease).

Steinbrocker, O., Traeger, C. H., and Batterman, R. C. (1949). J. Amer. med. Ass., 140, 659 (Therapeutic criteria in rheumatoid arthritis). 
L'effet de l'augmentation du taux sérique de sulfhydryl sur le titre du facteur rhumatoide

\section{RÉSUMÉ}

On dosa chaque semaine le taux de sulfhydryl sérique des malades ayant une polyarthrite rhumatoïde traités par trois composés sulfhydrés: D-pénicillamine, $\mathrm{N}$-acétyl $\mathrm{D}$ pénicillamine et mercaptoéthylamine, Tous ces produits provoquèrent une augmentation comparable du taux de sulfhydryl des protéines sériques dans les mêmes délais. Le titre du facteur rhumatoïde cependant ne baissa que lors de l'administration de D-pénicillamine. On en conclut que l'augmentation du taux du sulfhydryl sérique N'EST PAS le mécanisme par lequel la pénicillamine entraîne une baisse du titre du facteur rhumatoïde. La réactivité particutière du sulfhydryl de la molécule de la pénicillamine ou ses propriétés spécifiques de chélateur peuvent être responsables de l'effet de la pénicillamine sur le titre in vivo.
El efecto de las cifras aumentadas de sulfhidril en el suero sobre el título del factor reumatoide

\section{SUMARIO}

Se determinó una vez por semana la tasa del sulfhidrilos sérico en enfermos con artritis reumatoide tratados con $\Rightarrow$ tres compuestos de sulfhidril: D-penicillamina, $\mathrm{N}$-acetilos D-penicillamina y mercaptoetilamina. Todos estoso compuestos produjeron un aumento comparable de las cifras del sulfhidril de las proteinas séricas al cabo de un período similar. Las cifras del factor reumatoide bajaron sólo con la administración de D-penicillamina. Se concluye que la aumentación del contenido de sulfhidrih en el suero No ES el mecanismo mediante el cual la ${ }^{\infty}$ penicillamina produce una baja del título del factor $\overrightarrow{0}$ reumatoide. La reactividad particular del sulfhidril de la molécula de la penicillamina o sus propiedades queladoras específicas pueden ser responsables del efecto de las penicillamina sobre el título in vivo. 